\title{
Ecological trails in the specially protected natural areas of Altai Krai
}

\author{
N. G. Prudnikova, M. N. Ignatenko, A. V. Dudnik \\ Altai State University, Barnaul, Russia \\ E-mail: belukha@mail.ru, anikina-mn@mail.ru, rafting22@mail.ru
}

Received 07.11.2019 Accepted 26.12.2019

\begin{abstract}
The present paper provides results of studying the dynamics of ecological trails development in specially protected natural areas of Altai Krai. The study revealed the average number of the trails visitors, trail length, information content for educating students. Recommendations are given on the further development of this focus area and regular effective work on ecological trails. The authors identified the most attended ecological trails, studied the activities for schoolchildren and tourists on specially equipped trails in the wild. The article also examines the impact of the trails development on the environmental education of schoolchildren and the research work of students of the Department of Recreational Geography, Tourism and Regional Marketing of Altai State University (Geography Department) while developing the environmental routes.
\end{abstract}

Key words: Ecological trails; Specially protected natural areas; Altai Krai (Region); Environmental education; Development of ecological tourism

\section{Introduction}

Now-a-days, much attention is paid to the environmental education of schoolchildren; it is most effective to put these activities into practice in nature on specially equipped trails. Ecotourism is getting increasingly popular not only in the world, but also in Russia, and Altai Krai is no exception. The number of protected areas and ecological trails is growing. There is a rise in the protected areas visitors' quantity. More and more schoolchildren and student volunteers are participating in the development of ecological trails in the protected areas of the region. In the general site plan of the density of protected areas in Russia three years ago, the region was in the lower category, and the proportion of the protected area to the total area of the region was less than $5 \%$. But in the framework of the implementation of the Scheme for the development and deployment of Altai Krai protected areas for the period until 2025, the expanding work of protected areas in total has been carrying out and is ongoing concerning the arrangement of ecological trails. As of December 20, 2019, the protected areas of the region in total is 890.57 thousand ha. In 2015-2019, the share of protected areas in the total area of the region increased from 4.76 to $5.3 \%$. However, Altai Krai still takes the 10 th place out of 12 in the share of protected areas of the total area in the Siberian Federal District.

In Altai Krai, there are 107 operating specially protected natural areas of regional significance: The Tigireksky State Nature Reserve, 38 state nature sanctuaries, 67 nature landmarks, and Aya and Altai Foothills nature parks. There are many ecological trails in the region and their number is increasing, ecological tourism is actively developing in Altai Krai in plenty of districts, such as Zmeinogorsky, Sovetsky, Shipunovsky, Soloneshensky, Charyshsky, Krasnoshchekovsky, Altaisky and others. The maximum effect of education have the ecological trails.

\section{Methods}

The object of the study is presented by ecological trails in the protected areas of Altai Krai. The study has been conducted in 20152019. The research methods are the field observations, performed in accordance with the national standard (GOST R 56642-2015 Tourism services. Ecological tourism/Nature tourism. General requirements of 01.07.2106; GOST standard P 1.0-2012 Standardization in the Russian Federation. Basic provisions). The analysis of information for tourists and schoolchildren when organizing ecological tourism services was carried out in accordance with GOST standard 32612-2014 Tourist services. Consumer information.

\section{General requirements}

The purpose of the study is the analysis of regional ecological trails and its implications for the environmental education.

\section{Results}

A regional project Preservation of biological diversity and the development of ecological tourism has been developed and is being implemented gradually in Altai Krai. Currently, 10 ecological trails operate based on the protected areas of the region. According to the Ministry of Natural Resources and Ecology of Altai Krai, the number of active ecological trails in the protected areas of regional significance is eight. The process peculiarity of environmental training and education in the wild trails is that it is built on the basis of easy assimilation of information, value orientations and ideals, and norms of behavior in the natural environment. This is achieved by an organic combination of relaxation and learning while moving along the trail route. The main classification criterion of nature trails is their purpose, that can be cognitive-walking, educational-tourist, and actually educational ecological. Each type has its own specifics. According to the Ministry of Natural Resources and Ecology of Altai Krai, the following ecological routes are offered by the protected areas (Table 1 ). 
Table 1. Existing ecological trails in the protected areas of Altai Krai (compiled by the author and according to data of Prudnikova \& Dudnik, 2014; Ecological, 2019).

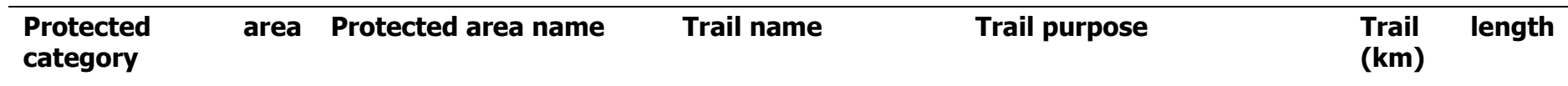

\begin{tabular}{|c|c|c|c|c|c|}
\hline Reserve & Tigireksky & Big Tigirek & & Educational-tourist & 70 \\
\hline Nature Park & Aya & - & & Cognitive-walking & 2.6 \\
\hline Wildlife Sanctuary & Pankrushikhinsky & - & & Educational & 2 \\
\hline Wildlife Sanctuary & Loktevsky & - & & Educational & 2.5 \\
\hline Wildlife Sanctuary & Yegoryevsky & - & & Educational & 1 \\
\hline Wildlife Sanctuary & Charyshsky & $\begin{array}{l}\text { Neglected } \\
\text { Landmarks }\end{array}$ & Natural & Cognitive-walking & 3 \\
\hline Wildlife Sanctuary & Swan's (Lebedinaya) & $\begin{array}{l}\text { Swan's } \\
\text { (Lebedinaya) }\end{array}$ & & Cognitive-walking & 1 \\
\hline Wildlife Sanctuary & $\begin{array}{l}\text { Waterfalls cascade in the } \\
\text { River Shinok }\end{array}$ & - & & Cognitive-walking & 3.5 \\
\hline Natural Landmark & Belfry (Kolokolnya) Mount & - & & Cognitive-walking & 2.5 \\
\hline Resort* & Belokurikha & Health Trail & & Educational-tourist & 24 \\
\hline
\end{tabular}

* Health-improving area (according to Federal Law-406 of December 30, 2013).

\section{Aya Nature Park (A/taisky District)}

A route of $2.6 \mathrm{~km}$ in length, attendance of 3.5-4 thousand people per season. It starts from the Shambhala campsite in the Aysky suspension bridge area over the Katun River through the birch and oak groves, the spruce forest, past the Mokhovoye swamp, rises to Mount Tserkovka and stretches along its crest to the Devil's Finger rock, which offers a picturesque view of the Katun River.

\section{Pankrushikhinsky State Natural Complex Sanctuary in the Pankrushikhinsky district}

Educational ecological trail, $2 \mathrm{~km}$ long; the average number of visitors is 1.5 thousand people per year (summer-autumn season). Children's Activity Center of the Pankrushikhinsky District organizes excursions for schoolchildren of the district (once a week, groups of 10-15 people).

\section{Loktevsky State Wildlife Complex Sanctuary in the Loktevsky District}

A $2.5 \mathrm{~km}$ long educational ecological trail. The average number of visitors is up to 500 people.

Yegorievsky State Wildlife Complex Sanctuary in the Yegoryevsky District: an educational ecological trail of about $1 \mathrm{~km}$ in length, attendance of 50-100 people.

\section{Charyshsky State Wildlife Complex Sanctuary in the Charyshsky district, village Mallorca}

Ecological trail Neglected Natural Landmarks, length is about $3 \mathrm{~km}$, attendance is up to 500 people.

\section{The Swan's State Wildlife Complex Sanctuary in the Sovetsky district}

the Swan's ecological trail length is of about $1 \mathrm{~km}$, attendance is of 1.5 - 2 thousand people (from November to March).

\section{State Wildlife Complex Sanctuary Waterfalls Cascade in the Shinok River in Soloneshensky district}

The length of the route is $3.5 \mathrm{~km}$, the attendance is 2-2.5 thousand people. The trail runs along the left bank of the river to the waterfalls Tender Mirage or Loose, Double Jump or Yogi, and Giraffe. The park has three information stands, six direction signs, four benches. Visual information is also placed in the sanctuary such as six stands, three direction indicators; a garbage collection area is organized. The nature landmark of regional significance Belfry Mount (Charyshsky district, $2 \mathrm{~km}$ from the village of Mallorca) is an ecological trail $2.5 \mathrm{~km}$ long. The average number of visitors is 100 people. Analysis of the attendance of ecological trails in 2019 according to the data of the Ministry of Natural Resources and Ecology of Altai Krai showed (Figure 1) that most often tourists visit the ecological trail in the Swan's Sanctuary of the Sovetsky District. This is due to many factors. Firstly, the annual Altai Overwintering holiday is held there, which is actively promoted by the Visit Altai Tourism Center of Altai Krai. Secondly, it is a guaranteed opportunity to see swans on a lake that does not freeze in winter, and thirdly, there is transport accessibility. 


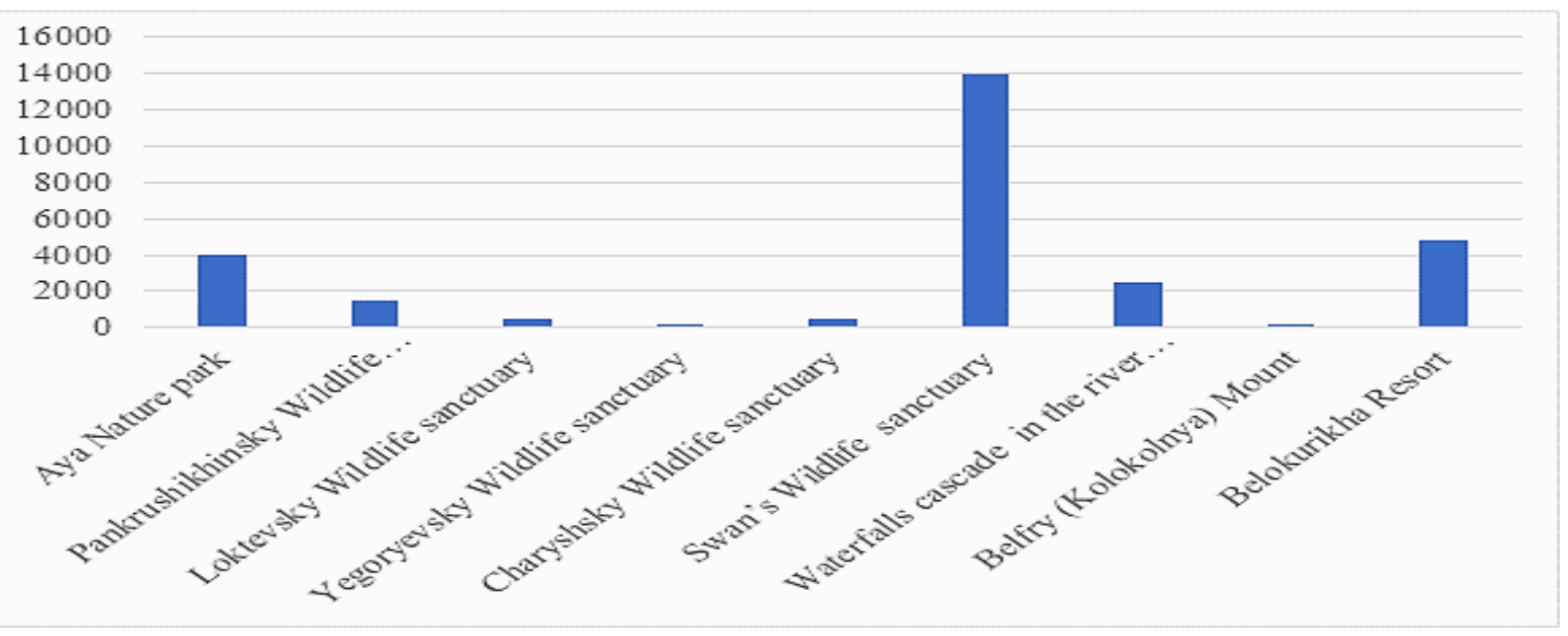

Figure 1. Analysis of the ecological trails attendance in 2019. The number of visitors is presented on X-axis.

High attendance of the trails of Belokurikha resort and Aya Natural Park are associated with a large number of tourists and vacationers who want to walk along beautiful mountain routes. Ecological trails within the boundaries of specially protected natural areas in the Altaisky and Soloneshensky districts are popular with many tourists and vacationers and visited on a regular base.

One of the directions of research work of the students of the Department of Recreational Geography, Tourism and Regional Marketing (Geography Department of Altai State University) is the development of environmental routes. In practical classes on environmental tourism, students have the goal of studying existing trails, developing new radial routes, arranging, and providing information for ecological trails. Students of the department conduct expeditions along the regional ecological trails annually. In 2014, specialists of Altaipriroda, as part of contracts implementation with the General Directorate of Natural Resources and

\section{Ecology of Altai Krai, created and equipped two ecological trails}

In Aya Nature Park and in Waterfalls Cascade Wildlife Sanctuary in the Shinok River. School children study information stands located in the park help to establish signs on the behavioral rules in the specially protected areas. Educational trails in Loktevsky, Yegoryevsky and Pankrushikhinsky Sanctuaries are already in demand for lessons with schoolchildren, whose attendance will increase. Working out new ecological trails is in permanent process. Here is an example of an ecological trail project for a rural house in a village Novokharkovka located in the territory of Mountainous Kolyvan Natural Park. One of the best ways to raise funds in protected areas is ecological tourism, which, if properly organized, can be cost-effective and at the same time contribute to nature conservation.

Another example of promoting environmental education, education and health of tourists with minimal damage to natural complexes is the ecological route Health Trail laid near the city-resort Belokurikha, the creation of which led to the following opportunities:

- Introducing tourists and vacationers of Russia sanatorium to ecological tourism;

- The solution of leisure issues of Russia sanatorium vacationers.

- Attraction of Belokurikha schoolchildren to excursions, which will raise the general level of environmental education in the city.

- Environmental education of route participants.

- $\quad$ Minimizing the negative consequences of tourism in the vicinity of the resort Belokurikha.

- Assistance of tourists to environmental protection (feasible participation in measures for cleaning, road furniture, planting, etc.).

- Fundraising from ecotourism, which can be invested to the protection of nature, monitoring, scientific research, trail development, Design of new ecological trails, creating new jobs for local residents.

- Job placement in Russia sanatorium, participation and work of local residents as guides, security workers, builders to get income, Which provides additional incentives for nature protection.

- The development of ecotourism in Tigireksky State Nature Reserve is being carried out by the Department of Ecological Education in collaboration with teachers and students of Altai State University. A crucial field of concern of Tigireksky State Nature Reserve is currently the development of ecological tourism. The Bolshoi Tigirek ecological trail has been set in the territory of the reserve, and work is currently underway to equip it.

The core factors for designing the ecological trail in the territory of Tigirek Reserve were:

- Availability of unique natural and historical-cultural objects;

- Necessity in extra financial resources for the reserve conservation, scientific research, monitoring;

- Demand for environmental education and education of tourists and local residents;

- Possibility of generating employment for the local population.

Tigireksky ecological trail route coincides with the routes of the most popular tourist hikes, which implies a certain load on the ecosystem. The implementation of this project will allow not only to form an ecological worldview among visitors, but also to teach them a careful attitude to the natural environment. In addition, extra job placement, obtaining economic benefits will serve as an incentive for the local population to protect the nature of their region. Tigirek - Mining (Razrabotnaya) Mount ecological trail will meet the needs of both specialists in the field of natural sciences and the general public, as its route passes through the unique natural communities of Altai Krai, and the availability of special recreation places, viewing platforms, and the accompaniment of a 
professional tour guide will create additional conditions for attracting ecotourists. Apart from the existing Big Tigirek ecological trail, two more trails are proposed. Nevertheless, for informational provision of the trail, design materials will certainly be required, offering the optimal solution for organizing environmental education on this ecological trail. This is a ground of the need for information banners, the development of their content, design, working drawings for production, and detailed reference materials for guides who are going to work with visitors on this trail. An ecological trail of interest to tourists is located on the trail between the information center of the reserve in the village Baranovka and its protected area called the Heart of the Jealous. Another ecological trail that is currently under development is called the Trail of Demidov ore dowsers. The route is designed for students and researchers in the field of natural sciences (botanists, zoologists, geographers, and hydrologists), families with children over four years. The maximum number of people in a group is seven-eight. The total length of the route is $1.5 \mathrm{~km}$. The development of a network of ecological routes in Tigirek Reserve will contribute to the parallel development of the totality of all elements of rural tourism, infrastructure and the way of farming, and will determine the conservation and development of the road network. If today the road leading to the village looks like an extreme attraction of entertainment, then, if there is at least an insignificant flow of tourists the conditions of travel will be improved. The financial opportunities of the inhabitants of rural houses allow them to maintain their income level and increase it thanks to the flow of tourists. The "soft", nature-friendly type of tourism in the protected area and in the territory of the reserve creates the conditions for job placement for residents of the village Tigirek. This also entails the preservation of wildlife and agricultural land.

\section{Conclusion}

In Altai Krai, there has been observed a significant amount of accumulated experience in the design of ecological trails in the framework of the development of ecological tourism. The development and further organization of ecological tourist routes (ecological trails) in various climatic conditions will contribute to the formation of an ecological worldview among schoolchildren and tourists. Also, as part of the environmental movement, when conducting environmental campaigns at mass tourist events held in Altai Krai, the participants pursue the study of water objects and their coastlines, identify ecologically disadvantaged places and sources of pollution, clean the coast from debris, improve traditional parking for vacationers, establish ecological posters. Recommendations on strengthening the trail canvas in three protected areas are proposed, an analysis of the degradation of trails over several years has been carried out. Altai State University students arranged camping sites; garbage collection campaigns are also held annually. For the regular effective work of ecological trails in the regional protected areas, it is necessary to complete the following work:

1) To monitor and implement comprehensive service of ecological trails by students;

2) Equip the route of ecological trails on the ground (strengthening the roadbed, installing information stands, etc.) based on design developments;

3) Provide resources for the maintenance of ecological trails (development of excursion programs, publication of guides, timely repair and updating of route elements);

4) Creation of interactive electronic databases on the Internet on the official websites of protected areas and Altai Krai Administration;

5) Training and employment of professional environmental tour guides;

6) The creation of the Ecotourism Agency within the framework of the Visit Center, coordinating and supervising the work of ecotour operators, developing routes, programs and regulations for visiting protected areas and other natural sites of Altai Krai;

7) The real attraction of local residents to ecotourism in the protected areas and beyond, increasing their employment and interest in this area.

The results of the project will be an increase in the ecological culture of the population, the promotion of active tourism as a form of healthy lifestyle, the education of children and youth through their involvement in tourism, local history and environmental activities. The planned development of ecological tourism without harming nature improves the image of the region, creates new jobs not only in tourism, but also in related industries (transport, hotels, medicine, education). However, it is important to remember that tourists are mostly attracted to Altai Krai by unique natural landscapes that are not destroyed by human activity. The mentioned recreational resources are the most important conditions for the further development of regional tourism.

\section{References}

Antyufeeva T.V., Mardasova E.V. (2013). Designing routes for the development of ecological tourism in the Altai region. Bulletin of Altai State University, 3-2(79), 138-141.

Ecological trail Big Tigirek. (2019). Available from: www.tigirek.ru.

Environmental education. (2019). website of the Ministry of Natural Resources and Ecology of Altai Krai. Available from: http://altaipriroda.ru/current_activities/ekoprosveshhen/.

Extension of the protected areas network. Ministry of Natural Resources and Ecology of Altai Krai. Availble from: http://altaipriroda.ru/news/oopt_?/2018/02/08/7319_rasshirenie_seti_oopt_v_2017_godu/.

Prudnikova N.G., Dudnik A.V. (2014). Using the potential of Aya Natural Park in tourism development. Using the potential of the protected areas for the development of ecotourism. Proceed. Sc. Conf., Barnaul.

Specially Protected Natural Areas of Altai Krai. Ministry of Natural Resources and Ecology of Altai Krai (Ministry of Natural Resources of Altai Territory). Available from: http://altaipriroda.ru/directions/prirodnye_resursy/oopt/ooptAK/.

The trail in harmony with nature. (2007). A collection of Russian and foreign experience in creating ecological trails. Moscow. "R.Valent". Available from: https://www.wildnet.ru/images/stories/bibl/Glava1.pdf/.

\section{Citation:}

Prudnikova, N.G., Ignatenko, M.N., Dudnik, A.V. (2019). Ecological trails in the specially protected natural areas of Altai Krai. Ukrainian Journal of Ecology, 9(4), 738-741.

This work is licensed under a Creative Commons Attribution 4.0. License 